\section{Performativa teatral como vínculo de la reparación social y dignificación desde el rescate de la memoria histórica intergeneracional ${ }^{1}$}

\author{
Nilcer Melgar y Johana Mejía
}

\begin{abstract}
Jamás se da un documento de cultura sin que lo sea a la vez de la barbarie. E igual que él mismo no está libre de barbarie, tampoco lo está el proceso de transmisión en el que pasa de uno a otro.
\end{abstract}

Walter Benjamin (1940)

\section{Resumen}

Palabras claves: memoria histórica, posmemoria, performativa, teatro, conflicto armado, reparación social, dignificación, procesos, psicosociales.
Estudiar los actos performativos implica dar una mirada crítica de lo que significa dignificarse como seres humanos desde el reconocimiento colectivo de la barbarie hasta la búsqueda de la liberación. Esta investigación parte de la teoría de la posmemoria, noción elaborada por Marianne Hirsch y los aportes de la psicología social acuñados por Ignacio Martín-Baró. Estos encuadres han sido utilizados para analizar los vínculos intergeneracionales de las comunidades repobladas del nororiente de Chalatenango para estudiar el impacto psicosocial ocasionado por el conflicto armado de acuerdo con los procesos psicointercomunitarios que han quedado manifiestos en el posconflicto, mediante el reconocimiento y la implementación de la rama artística, específicamente el teatro. Los resultados evidenciaron que, efectivamente, la performativa teatral ha activado procesos que han contribuido a la reparación social y a la dignificación desde y hacia las víctimas. Es decir, el teatro se ha convertido en una herramienta de resistencia utilizada como denuncia y reconstructora del tejido social dañado. A través de este, las comunidades establecen

$1 \quad$ Este artículo está basado en la tesis de graduación de las autoras para optar al título de Maestra en Intervención Social en la Universidad Centroamericana José Simeón Cañas en 2021. 
una comunicación afectiva intergeneracional, consolidan el sentido de pertenencia comunitaria, instalan un posicionamiento político público y movilizan sus capacidades de agencia.

\section{Introducción}

El discurso sobre memoria histórica se construye en un contexto fechado, desde una interpretación del pasado a través del presente. Lara-Martínez (2018) destaca que esto condiciona la forma y el contenido de ese discurso. En esta investigación, se estudia el contexto de la sociedad salvadoreña bajo la lupa de las comunidades del nororiente de Chalatenango, las que fueron víctimas de violencia ejercida durante el conflicto armado en El Salvador. Lara-Martínez (2018) destaca que estas comunidades están dialécticamente articuladas, unidas con un fuerte arraigo a partir de la herencia histórica que les dejó la guerra y la posguerra, lo que concreta su identidad comunitaria. El autor hace hincapié en que la cultura de estas comunidades se deja ver en actividades religiosas (fiestas patronales, vigilias) y aniversarios natalicios de los municipios. A esto se suman las celebraciones que realizan para recordar sus repoblaciones y para no olvidar las masacres y más hechos dolorosos que han marcado su dinámica social. Precisamente esta dinámica sociocultural e histórica, que impactó el tejido social a través de la violencia ejercida hacia la población, es la que motivó el desarrollo de esta investigación. Y en este marco, se estudió si la performativa teatral iniciada durante el conflicto armado, en estas comunidades, ha contribuido a generar procesos de reparación social y dignificación. La performativa teatral, en este contexto, fue entendida como las expresiones de arte que las comunidades desarrollan alrededor de la convergencia artística teatral desarrollada a partir de la historia comunitaria que les identifica: escenas de masacres, guindas, torturas, éxodos, entre otros; acontecimientos vividos durante el conflicto armado y retratados en eventos socioculturales simbólicos. Entre estas comunidades, existe una historia común. La mayoría son sobrevivientes de la barbarie y desde ahí valoran su existencia en comunidad.

Ascoli (1994) documenta que, durante la época poscolonial, Chalatenango se convirtió en un departamento marginado, pues la producción del añil dejó los territorios erosionados e infértiles. Esto provocó que los pobladores se convirtieran en mano de obra barata en las nuevas estrategias económicas de los terratenientes. Durante la segunda mitad del siglo XIX, en los periodos de cosecha, ellos se trasladaban temporalmente, en bandadas, a las plantaciones de café, caña de azúcar y algodón para aprovechar la cosecha, tener un mínimo de empleo y un salario que cubriera sus necesidades más urgentes. Sin embargo, ahí encontraban la misma realidad de miseria. El pago no era suficiente para cubrir sus necesidades básicas y el trato laboral era inhumano. Esto generó un descontentó popular y exigencias tales como un mejor salario y mejores condiciones de vida social-humana laboral. La respuesta a estas exigencias fue persecuciones y represión por parte del Gobierno de turno (Ascoli, 1994). Este desplegó cuerpos de seguridad para detener las manifestaciones en la ciudad y en las comunidades. Realizaban retenes en puestos militares y en sitios estratégicos. Al ver que la organización popular no se detenía, la Organización Democrática Nacionalista (ORDEN), la Guardia Nacional y más escuadrones de la muerte se alarmaron y echaron encima las patrullas cantonales para vigilar las poblaciones. Según Ascoli, los patrulleros eran personas de las mismas comunidades que ejercían trabajo de vigilancia. Finalmente, se convirtieron en organizaciones escuadroneras, llamadas en la zona "orejas"2 de ORDEN. Esta organización fue creada en 1964 para defender la patria ante la supuesta "influencia comunista" que provenía de Cuba. Llamaban

2 Miembros de las patrullas escuadroneras para vigilar el comportamiento organizativo de los miembros de la comunidad. Actividad que consideraban subversiva frente al orden nacional. 
a las organizaciones campesinas subversivas y comunistas.

Ascoli narra que ORDEN, la Policía de Hacienda y la Guardia Nacional habían desarrollado un plan de represión selectiva a través de los "orejas". Los seleccionados para esta organización llegaban a las reuniones y "ponían el dedo"3 a las personas de la comunidad. Hacían una lista de la gente a quienes habían detectado como organizados (subversivos) y la entregaban en los puestos de la Guardia Nacional. Con esta información, se "capturaba a la gente, la torturaban y asesinaban a los que consideraban sospechosos" (Ascoli, 1994, p. 41).

Las comunidades del nororiente de Chalatenango durante la guerra huyeron de sus hogares para protegerse de estas constantes violaciones a su seguridad por parte de las organizaciones paramilitares. La mayoría de los actuales pobladores vivieron en pequeñas comunidades en la zona de Arcatao, Nueva Trinidad, Nombre de Jesús, Patamera, San José Las Flores, Las Minas, La Cañada, Los Filos, El Chupamiel, entre otras. Algunos, con la promesa de tener "un seguro de vida", decidieron viajar en familia al campamento de refugiados en Mesa Grande, Honduras, ofrecido por la Agencia de la ONU para los Refugiados (ACNUR). Otros pobladores de la zona se quedaron cerca de sus comunidades expuestos al hambre, adversidades climáticas y la violencia de los militares. Sprenkel (2012), en su artículo "La guerra como controversia", valida que el conflicto armado fue un escenario de fuertes violaciones a los derechos humanos. Asegura que la proporción mayoritaria de los "80,000 muertos y miles de desaparecidos no era militar ni murió combatiendo, sino que fue víctima de una persecución política por parte de aquellos que los habían identificado como posibles opositores" (p. 69). Del mismo modo, la Organización de las Naciones Unidas (1993) confirmó que, aunque el conflicto afectó a todos los sectores del país, la abrumadora mayoría de las personas asesinadas y desaparecidas pertenecían al campesinado.

\section{Conflicto armado: "la negación de la negación"}

El Salvador de la posguerra, no dista de las condiciones de vida cuyas causas estructurales impulsaron el inicio del conflicto armado. Oxfam (2015) enfatiza que algunas de las dificultades que la ciudadanía enfrentó se debieron a la extrema concentración de la riqueza entre unos pocos, a la concentración del poder en cúpulas conservadoras del status quo que interfirieron en los avances de las esferas sociales, económicas, laborales y políticas, convirtiéndolas en desafíos casi inalcanzables para las mayorías populares, dando como resultado un Estado desigual, inequitativo, injusto y violatorio de los derechos humanos.

Para Ribera (2003a), "únicamente el mirar al final de un proceso es cómo se comprende su inicio y las etapas que lo componen" (p. 667). A nivel del conflicto armado salvadoreño, esta lógica compone un "movimiento dialéctico" donde una fase explica la otra a cabalidad. El historiador pone su punto de partida desde "la negación de la negación". Es decir, desde el periodo de paz de 1992, periodo histórico que, según argumenta, no se puede explicar sin los años anteriores. A este periodo lo precedió la primera fase: "una historia de guerra, mientras a la segunda, una historia de paz" (Ribera, 2003a, p. 668). El historiador comenta que "la guerra había surgido de su opuesto, de la paz de los años setenta" (Ribera, 2003a, p. 668), pero esta presentaba su carácter falso, pues incubaba el conflicto por venir siendo la guerra de los ochenta la negación de la paz de la década anterior. A su modo, Hernández Rivas y Chévez Reynosa (2018) entienden que la guerra civil que devastó al país de 1980 a 1992 fue, en gran medida, el resultado del

3 Traslado malintencionado de información para señalar acciones de personas que se consideran, ideológicamente, de bando contrario. 
autoritarismo militar y del cierre gradual de los espacios de disenso político.

\subsection{Hechos históricos que desencadenaron el conflicto armado de El Salvador}

Los eventos que marcaron la historia del país, principalmente en la zona del nororiente de Chalatenango previo, durante el conflicto y el posconflicto, se registran como: (a) concentración de la riqueza, desigualdad social y Reforma Agraria; (b) golpe de Estado de 1979; (c) muerte de monseñor Romero, y (d) movimientos sociales, organizaciones político-militares y ejército revolucionario.

En El Salvador, la concentración de la tierra, la gran cantidad de latifundios y la enorme disparidad en el acceso a la propiedad daban como resultado el aumento exponencial de los minifundios; así, se dejó ver la necesidad de poner en agenda política acciones encaminadas en una Reforma Agraria (Aguiluz, 2014). La tenencia de la tierra por parte de la oligarquía terrateniente exponía al campesinado a solamente ofrecer su fuerza de trabajo a través del empleo precario en las características plantaciones de café (Merino et al., 2011). En medio de este panorama, las zonas rurales del país se perfilaban como el blanco de nuevas formas de explotación. Esto agudizaba la marcada "institucionalización de la pobreza".

El panorama de crecimiento de las organizaciones campesinas, manifestaciones $y$ exigencias sociales provocó que el Gobierno militar de Arturo Armando Molina se atreviera a realizar el planteamiento de una Reforma Agraria. Esta reforma formaba parte de una propuesta de desarrollo social, basada en el cambio de la dinámica de tenencia de la tierra. Fue por ello por lo que, en 1975, Molina conformó el Instituto Salvadoreño de Transformación Agraria (ISTA) (ECA, 1997). $\mathrm{Al}$ año siguiente, presentó un proyecto que consistía en la compra de 59,000 hectáreas de tierra por parte del Estado, para ser destinadas a 12,000 familias campesinas. Sin embargo, la
Asociación Nacional de la Empresa Privada (ANEP) se opuso, presionando al Gobierno, quien dio marcha atrás en la modificación del decreto de creación del ISTA (Molina y Kovalskis, 2017). Esto provocó ciertas barreras jurídico-sociales, haciendo expropiables únicamente las tierras que no cumplieran con la función social de la propiedad (ver Ley del ISTA, p. 14). Además, las fuerzas políticas que se impusieron al Gobierno buscaron su revancha sobre quienes se habían manifestado a favor de la Reforma Agraria y aplicaron una línea de terror hacia las organizaciones y movimientos populares, llevando la represión intensamente al campo y a los dirigentes de organizaciones (Montes, 1986a).

Para Ribera (2003a), la violencia con la que se arremetía a la población civil en el país se aceleró desde "el fraude electoral de 1977 y tenía un claro repunte en 1979 con la confrontación militar" (p. 673). El 15 de octubre de 1979, los militares jóvenes del ejército salvadoreño dirigido por el coronel Majano tomaron el poder del país y derrocaron al presidente Carlos Humberto Romero, electo por voto fraudulento por el Partido de Conciliación Nacional (PCN). En ese año, el país se encontraba subsumido en un ambiente donde los sectores poblacionales mayoritarios exigían soluciones a sus problemáticas (Grenni, 2008a) y se encontraban frente a un poder político que carecía de representatividad y credibilidad, tanto por su forma de acceder al poder, como por su incapacidad para dialogar con los diversos sectores de la sociedad civil. Fue un gobierno incapaz de crear los espacios institucionales para un reparto equitativo de la riqueza. Además, en ese tiempo, los movimientos sociales alcanzaron dimensiones que hicieron peligrar la estabilidad del sistema. Ribera (2003a) expone que, pese a las características violentas de la acción cometida por la Junta Militar Democrática, se ponía fin a casi cincuenta años de dictadura militar.

En medio de este periodo de fuertes transportaciones sociopolíticas y económico-sociales, en 1977, monseñor Oscar Arnulfo 
Romero asumió su cargo como arzobispo de San Salvador. Hasta entonces, su vida se había desarrollado con normalidad. "Era considerado un obispo espiritualista, devoto y apostólico, más inclinado a la componenda con los poderosos que a la solidaridad con los marginados" (Grenni, 2008a, p. 30). Sin embargo, las circunstancias políticas durante su nombramiento se dieron en el marco de años represivos y con el aumento de muertes de campesinos. A los pocos días de asumir su trabajo en San Salvador, el 12 de marzo de 1977, recibió la noticia del asesinato de dos campesinos y su amigo el sacerdote Rutilio Grande, quien había contribuido decididamente a la defensa de los derechos de los campesinos en Aguilares, al norte de la capital salvadoreña. El crimen nunca quedó aclarado. Las personas cercanas al obispo comentan que, probablemente, desde ese momento tomó la opción de estar más cerca de los sectores marginados (Cardenal, 2008). Desde ese tiempo, en sus homilías, abordaba problemáticas de la realidad nacional y aprovechaba para provocar actividades en defensa de los derechos de los más desposeídos. Todo esto fue visto como amenazante por la clase dominante del país y el 24 de marzo de 1980 fue asesinado por un francotirador mientras celebraba una misa en la capilla de la Divina Providencia, en la capital salvadoreña (Grenni, 2010b).

Paralelamente a este acontecimiento, los movimientos sociales tomaban mayor conciencia, unidad y organización en diversos puntos, los cuales buscaban nuevas redes de apoyo para lograr incidir sobre las condiciones socioeconómicas del país (ECA, 1997). Había movimientos campesinos, estudiantiles, sindicatos y gremios profesionales que se involucraron política e ideológicamente. Buscaban expandir su acción sociopolítica y con la que apuntaban que se había roto la barrera fatalista de la realidad social (Montes, 1986a, p. 67). Estos movimientos cada vez canalizaban el descontento social, especialmente en las regiones rurales, montañosas y alejadas de la capital, en particular en los departamentos de Chalatenango y Morazán, limítrofes con Honduras (Grenni, 2008a). En este contexto, los movimientos sociales optaron por luchas sociales revolucionarias/ militares como el medio idóneo para enfrentarse al régimen. Como consecuencia, la vía de la lucha armada irrumpió en la ciudad y las comunidades rurales. Ribera (2003a) comenta que, a partir del 10 de enero de 1981, ya eran claramente dos ejércitos los que se estaban enfrentando. Es decir, el bando guerrillero conformado por el FMLN y las Fuerzas Armadas que buscaban salvaguardar el status quo impuesto por los gobiernos de turno. En 1982, el país había entrado ya al periodo denominado de "guerra total".

\subsection{Hechos deshumanizantes durante el conflicto armado}

Martín-Baró (1983a) recalca que, desde 1981, El Salvador profundizaba sus raíces en una historia de opresión secular (p. 359). Mientras tanto, el informe de la Comisión de la Verdad retomó el periodo entre 1980 y 1992 como un lapso de guerra que hundió a la sociedad salvadoreña en la violencia y reiteró que esta violencia fue una llamarada que invadió hasta los "recintos íntimos" (ONU, 1993). Martín-Baró (1983a) examina estas acciones violentas como una fuerte dosis de crueldad que hacían una práctica sistemática de la tortura. Menciona que era raro el cadáver que no presentaba muestras de violación y daños físicos en el cuerpo, a menudo deformados. Otra de las violencias que nombra es el descuartizamiento y el exhibicionismo macabro: "cadáveres que aparecían diseminados en pedazos en las cunetas o arrojados en los basureros, madres con el vientre abierto y el feto cortado a trozos, cabezas sin cuerpos expuestos con letreros firmados por algún escuadrón de la muerte" (Baró, 1983a, p. 164).

Es evidente que todos los hechos ejecutados durante el conflicto tuvieron una gran incidencia en el cambio de las relaciones sociales en la población de Chalatenango. Sin embargo, en esta investigación se toman en cuenta cinco hechos relevantes: la masacre 
de Las Aradas, la Guinda de Mayo, el periodo de refugio en Mesa Grande (Honduras), la repoblación y la reconstrucción de las comunidades.

\subsubsection{La masacre de Las Aradas}

Uno de los ataques de ejecuciones sumarias es el cometido en las riberas del río Sumpul el 14 de mayo de 1980, donde "contingentes del Destacamento Militar $\mathrm{N}^{\circ} 1$ de ORDEN dieron muerte deliberadamente a un número no inferior a trescientas personas no combatientes, inclusive a mujeres y niños que intentaban cruzar el río Sumpul" (ONU, 1993). Según testimonios de sobrevivientes, fueron más de seiscientas personas las masacradas y aseguran que en el hecho también participó el ejército hondureño, impidiéndoles el paso al vecino país. ONU (1993) detalla que la aparición del terrorismo organizado se convirtió en una de las prácticas más aberrantes del proceso bélico. "Grupos civiles y militares practicaron asesinatos con tal impunidad en forma sistemática, bajo el amparo displicente de instituciones del Estado" (p. 19). Ascoli (1994) documenta que la táctica militar que utilizaron los paramilitares fue "yunque y martillo"4.

\subsubsection{La "Guinda de Mayo"}

Otro evento que evidencia la barbarie que enfrentaron las comunidades del nororiente de Chalatenango es el operativo militar denominado la "Guinda de Mayo", ocurrida en 1982. Los testigos del acontecimiento relatan que fue el resultado de múltiples operaciones militares y que los atacaron por varios días y desde distintos puntos de los departamentos de Chalatenango y Cabañas. Gran parte de la población fue emboscada y masacrada. Para la población esto fue "una persecución continua, una guinda" (Radio Farabundo Martí, 2020). La Asociación Pro-Búsqueda, que ha brindado apoyo social y psicosocial a las víctimas desde su creación en 1993, comenta que fue un operativo que inició el 27 de mayo y duró hasta el 9 de junio de 1982. En esta operación militar, el ejército ejecutó varias masacres en diferentes zonas donde encontraban la población civil, destruyeron propiedades y cultivos. Lo más grave, asegura la institución, fue el asesinato de la población campesina y que el ejército se llevó a 53 niños y niñas. Muchos de estos niños y niñas fueron entregados a las damas voluntarias de la Cruz Roja Salvadoreña (Asociación Pro-Búsqueda, 2013).

El operativo correspondía a "operaciones militares combinadas 'tierra y aire' de la Fuerza Armada, con los que intentaba recuperar el control en zonas controladas por los rebeldes" (ONU, 1993). La Guinda de Mayo es recordada por las comunidades por la muerte de campesinos, asesinados en múltiples masacres y ahogados en el río Sumpul. En el 2020, la Radio Farabundo Martí conmemoró el genocidio vía virtual y aseguró que en 1982 la Fuerza Armada salvadoreña denominó al operativo "Tierra Arrasada", donde asesinaron a no menos que 200 campesinos y desaparecieron a un número que todavía no se tiene exactitud. Con la ideología de eliminar el comunismo, lanzaban estos operativos a los que llamaba "quitarle el agua al pez", pues aseguraba que, al minimizar la población civil, la guerrilla no alimentaba su número de efectivos (Ascoli, 1994).

\subsubsection{El refugio en Mesa Grande, Honduras}

Montes (1985b) evidencia, en sus investigaciones de los años ochenta, que "la población rural y urbana que logró escapar a la captura o a la muerte violenta, trató de cruzar la frontera: 'refugiados', o de buscar lugares más seguros dentro del territorio nacional: 'desplazados', ya sea en forma concentrada y bajo protección de alguna

\footnotetext{
4 Táctica militar mejor conocida como "tierra y aire" o "tierra arrasada", que comprendían bombardeos aéreos y persecuciones terrestres hacia la población campesina durante la guerra civil salvadoreña. Según los destacamentos militares, era para quitarle elementos paramilitares a la guerrilla.
} 
institución” (p. 2). Montes registró que en la intensificación de la represión y la continuación de la guerra civil aumentó la cifra de refugiados y desplazados, llegando al "medio millón (10\% de la población supuesta) de desplazados" (Montes, 1985b, p. 2).

Las comunidades del nororiente de Chalatenango iniciaron su peregrinar a tierras extranjeras a partir de los intensos operativos. Después de la masacre de Las Aradas migraron a La Cañada, El Chupamiel, Los Filos y El Portillo, territorios fronterizos con Honduras. Ahí formaron su primer campamento (Ascoli, 1994) y permanecieron por algún tiempo. Sin embargo, en este periodo, estas comunidades decidieron aceptar el apoyo de ACNUR y viajaron a los campamentos de Mesa Grande para estar más seguras.

Las viviendas provisionales de Mesa Grande eran grandes carpas hechas de lona que dependían desde el techo, con palos en las orillas. Las dividían para que se acomodaran las familias, hasta tres en una misma. Al cabo de unos años, estas carpas de lona fueron reemplazadas por galeras de madera, casas largas, a las que la gente insistía llamarles "barracones" (Melgar, 2015). Mesa Grande estaba custodiada por un cerco de alambre, desde el cual las personas eran asediadas por el ejército hondureño. En muchas ocasiones, sus compañeros de campamento fueron capturados y desaparecidos por este cuerpo institucional (Ascoli, 1994).

\subsubsection{La repoblación y la reconstrucción de las comunidades: la liberación de un pueblo}

Ascoli (1994) sostiene que la primera repoblación espontánea fue en Arcatao, en 1984, de las personas que andaban en la guinda. A mediados de 1985, San José Las Flores repobló esa comunidad que había quedado abandonada por sus antiguos nativos. Desde ese momento, se inició el apoyo en conjunto con monseñor Rivera. Entre 1986 y 1988, las repoblaciones de Guarjila, San Antonio Los Ranchos, Las Minas y Las Vueltas negociaron su retorno al país. La primera propuesta para ellos era adentrarse en tierras hondureñas. Sin embargo, las poblaciones esperanzadas en el regreso a su país manifestaron que querían regresar a El Salvador, a los lugares donde habían nacido. Querían viajar a Guarjila y a Las Vueltas (Chalatenango), a Copapayo (Cuscatlán) y a Santa Marta (Cabañas) (Ascoli, 1994).

En el refugio, vivieron alrededor de siete años. Entre 1986 y 1988 se reunían con organizaciones del Estado salvadoreño, con la Iglesia, con el FMLN y con la solidaridad internacional para proponer la idea de repoblar en comunidad para protegerse mutuamente de los bombardeos que se daban entre la guerrilla y el ejército. Cuando pudieron realizar el éxodo, llegaron a un territorio minado, pero un lugar que los acercaba a sus hogares anteriores. Desde que llegaron, los repobladores comenzaron a reconstruir sus nuevas comunidades (Lara-Martínez, 2018).

Lo representativo durante la reconstrucción de las comunidades fue el colectivismo. Desde que llegaron, notaron las dificultades para reiniciar una vida social a nivel de desarrollo humano aceptable. Fue por ello por lo que continuaron con el modo de vida comunitaria que aprendieron en los campamentos: tener milpas, hortalizas y una granja comunitaria para obtener los alimentos indispensables. A esto se agregaba: una carpintería, una escuela, una clínica, una radio y talleres de sastrería, bordado y más. Construyeron sus primeras viviendas con zacate. No obstante, en el tiempo provisional, entre familiares, vecinos $y$ conocidos se apoyaron en la mezcla del lodo, vara de bambú, transporte de tierra y piedras para hacer sus casas de bajareque ${ }^{5}$. Los servicios básicos también se lograron en comunidad: agua, salud, educación, electricidad, entre otros.

5 "Pared de palos entretejidos con cañas, piedras y barro" (RAE, 2020). 
Cuando se toca el tema de las comunidades repobladas de Chalatenango, se tiene claro que son comunidades unidas por una misma historia y una misma memoria colectiva. Su reconstrucción representa en la actualidad una acción social que se sigue practicando desde la esperanza de liberación que se vivió en los campamentos.

\section{Aspectos teóricos para el análisis del conflicto y el posconflicto}

Los conceptos centrales que dirigen la estructura de la investigación se retomaron desde las teorías de la psicología de la liberación y comunitaria, memoria histórica, posmemoria, pedagogía de la educación liberadora, teatro del oprimido, abordadas a partir de los aportes de Martín-Baró, Lira, Gaborit, Montero, Hirsch, Freire, Boal y Adorno.

Para Martín-Baró (1988), la memoria histórica "facilita poder vivir en verdad y desde la verdad y, en consecuencia, posibilita la salud mental de los individuos, en especial, la de aquellos que se encuentran en etapas críticas, en la formación de sus identidades" (Martín-Baró 1988, en Gaborit, 2006, p. 12). En las sociedades donde se han violentado los derechos humanos, la memoria histórica sienta las bases para otorgar a estas poblaciones un reconocimiento de su dolor a través de la justicia.

En esta investigación es importante señalar que memoria histórica no se reduce a los acontecimientos de guerra. Este concepto es, sin duda, uno de los más amplios y de los que estrechamente se relacionan con la memoria. Sin embargo, al tener en cuenta la realidad histórica de las comunidades repobladas de Chalatenango, en la presente investigación, se entenderá el concepto de memoria histórica desde una interpretación del pasado a través del presente de estas poblaciones. Por tanto, memoria histórica significa reconstruir los juicios políticos y éticos de los acontecimientos, vistos desde el olvido jurídico (amnistía), el olvido traumático (amnesia) y el olvido subjetivo (atenuación de las emociones). Además, implica fechar y situar los acontecimientos encaminados a un logro popular que permita a los pueblos ser protagonistas de su propia historia y que esto les permita lograr cambios que hagan a las sociedades más justas y humanas (Lira, 2004; Martín-Baró, 1998).

Dentro de la conceptualización sobre memoria histórica, la posmemoria se posiciona como parte de ella. Desde ahí, expone las manifestaciones que son develadas por las generaciones posconflicto. Expresiones simbólicas y performativas se cargan de la vivencia del testigo y se sacan a la luz con el apoyo de los herederos para poder posicionarse públicamente y gestar de manera paulatina una dinámica relacional psicoafectiva de sanación. Es decir que, teórica y prácticamente, estos conceptos no van desvinculados. Ambos contemplan la verdad y la justicia como herramienta política y ética para garantizar la no repetición de actos atroces ocurridos en dictaduras y guerra civiles.

El término "posmemoria" surge a finales de los años ochenta dentro de los estudios de memoria para analizar artefactos culturales que trabajan sobre la perdurabilidad, la transmisión de experiencias traumáticas a través de distintas generaciones. La noción fue elaborada por la crítica literaria norteamericana Marianne Hirsch en el marco de expresiones culturales producidas por la segunda generación del Holocausto, es decir, por los hijos e hijas de los sobrevivientes (Szurmuk, 2009). Hirsch formuló la noción en su libro Family Frames (1997), en el que analizaba los usos de la fotografía en procesos de posmemoria familiar. También señalaba que la posmemoria supone un trabajo de elaboración crítica, imaginativa y artística sobre los relatos heredados.

En la posmemoria, el arte presta su protagonismo en el hecho de hacer memoria. En tal sentido, la posmemoria se manifiesta explícitamente en las generaciones posconflicto, cuyas expresiones son expuestas a partir de reelaboraciones de las experiencias individuales y colectivas que emanan como 
producto del rescate de la memoria histórica. La posmemoria cobra vida dentro del auge testimonial y el archivo de la memoria, nutriéndose de estos para elaborar el performance, refleja la necesidad de crear estructuras institucionales y estéticas que den cabida a las prolíficas obras de arte, memorias que analicen y describan el parentesco de los actores sociales con el pasado (Hirsch, 2012). En contextos de larga historia de represión, los testigos de los acontecimientos representan a quienes heredan a las nuevas generaciones un trauma histórico a través de emanaciones (atisbos cotidianos verbales o no verbales) y un caos de emociones, destellos de imaginación (abruptos-quebrados), los cuales constituyen un retorno traumático al cual Hirsch llama "conexión viva entre generaciones". Son diversas experiencias traumáticas que convierten a las nuevas generaciones en nietos y nietas de "guindas", de masacres y de refugios, y desde ahí resignifican su subjetividad (Cianco, 2015).

La transmisión intergeneracional es un vínculo afectivo entre el pasado y el presente donde las estructuras memoriales se convierten en actos performativos que rescatan la memoria histórica de una población de posguerra. En ellas, los testigos y las nuevas generaciones comparten sus memorias traumáticas desde distintos ángulos, planos y escenas (Cianco, 2015), y se posicionan ante ellas mediante el performance para reactivar el vínculo con lo familiar, el grupo social y el archivo institucional (Warbury, 1929, en Hirsch, 2012).

Con base en lo anterior, en la presente investigación se entiende el término "puente intergeneracional" como la afiliación identitaria entre generaciones integrada por una dimensión de herencia histórica de barbarie y, también, de una dimensión de unión donde ambas generaciones comparten la necesidad y el deseo de reparar y trascender estas experiencias (Hirsch, 2012; Cortina, 2015).

Ligado al tema de la memoria histórica y la posmemoria, Martín-Baró, desde el enfoque psicosocial, hacía énfasis en el impacto de la guerra y cómo esta afectaba la salud mental de las personas y grupos, no solo en un sentido patológico clásico, sino deshumanizando las relaciones sociales más fundamentales. Ponía su mirada en las relaciones deshumanizantes a las cuales miraba como un cúmulo de acciones enajenantes donde se concibe a las demás personas como desiguales, y en las cuales se busca a toda costa salvaguardar ciertos intereses personales o grupales, dando lugar a la legitimación de la violencia, reflejada en torturas y desprecio a la vida de los demás por sus características físicas, sociales, psicológicas, ideológicas, culturales y/o económicas (Martín-Baró, 1990; Samayoa, 1987-1990; Oropeza, 1990). Ante el contexto violento de la guerra civil, MartínBaró propuso "el trauma psicosocial como una experiencia que afecta y deja un residuo permanente en la persona" (Martín-Baró, 1998c, p.135). Enfatizó el carácter dialéctico de la herida causada por la vivencia de la guerra, la vivencia peculiar de la persona, la vivencia condicionada de acuerdo con su extracción social, por su grado de participación, entre otras características (Martín-Baró, 1984d).

Ante la realidad de barbarie experimentada por las comunidades repobladas, el enfoque psicosocial es una forma de aproximación al ser humano que inspira un conjunto de prácticas, valores y estrategias de acompañamiento (Claustro Escuela de Psicología UBB, 2012). Este abordaje plantea la liberación como una alternativa para hacer posible la sanación de las víctimas y la liberación de los pueblos de las estructuras opresoras. La liberación tenía que ir encaminada a una relación dialéctica sobre una nueva concepción teórica y una nueva praxis, donde los procesos psicosociales se encaminan a la idea teórico-práctica: "sufrir con sentido". Desde esta perspectiva, la persona sobreviviente encuentra en sí misma o en los y las demás formas de reconfortarse, autocrearse y madurar ante las vivencias dolorosas (Martín-Baró, 1964f). Esto permite a la persona vulnerada transitar desde una perspectiva de víctima a una de sobreviviente. 
Así, la persona adquiere control sobre su propia existencia y se posiciona con dignidad frente a las relaciones deshumanizantes y de dominación experimentadas (Martín- Baró, 2006e). En tanto ello, esta investigación concibe los "procesos psicosociales" como los mecanismos subjetivos $e$ intersubjetivos que se orientan a revertir las determinantes de la deshumanización, a través la búsqueda de la transformación social, la trascendencia y la reelaboración de esas experiencias de vida provenientes de relaciones injustas en una estructura social violenta (Martín-Baró, 2006). Incluye en ellos, la reflexión de los mecanismos subjetivos $e$ intersubjetivos mediante los cuales las personas y grupos reconocen y reelaboran las experiencias traumáticas e injustas vividas durante el conflicto armado. Estas reflexiones contribuyen a la transformación de las determinantes de estas; permiten, además, la concientización y el reconocimiento de su valor intrínseco. Además, desarrollan procesos de memoria histórica, dignificación, reparación del daño, crecimiento personal y colectivo, en contraposición a las relaciones sociales marcadas por experiencias dolorosas en contextos de barbarie (Martín-Baró,1990).

La dinámica social entre generaciones en las comunidades repobladas de Chalatenango también visualiza el vínculo con el pasado desde el fortalecimiento de la comunidad. Según Montero (2010), la comunidad es esa estructura social que busca un desarrollo y fortalecimiento común. Su origen se centra en la acción social, la cual Martín-Baró define "como aquellas estructuras y procesos mediante los cuales los seres humanos conciben intenciones simbólicas y tratan de realizarlas en situaciones concretas" (1989, p. 21). La acción social hace ver a los miembros como actores sociales constructores de su realidad, dejándose de considerar como sujetos pasivos (Montero, 1982; 1984). En las comunidades repobladas de Chalatenango, esta relación humana se vincula al sentir comunitario que nace a raíz de la barbarie, de la persecución y el sufrimiento. Esto mismo permite vislumbrar una luz de esperanza y fe que posibilita la solidaridad, la cooperación y el fortalecimiento común en la búsqueda de una sociedad dignificante, donde se pueda vivir en paz, con amor y entrega; donde se pueda gozar del respeto y se reconozcan la vulneración y la humillación histórica a la que se sometió a dicha colectividad (MartíBaró, 1989). Por tanto, en esta investigación se entendió "identidad comunitaria" como el vínculo de relaciones sociales de un pueblo que se encamina a reconocer $y$ vivir su libertad a partir de la unión solidaria donde se reconocen las relaciones injustas y se resiste colectivamente mediante la cooperación y el fortalecimiento que les lleva a dignificarse (Montero 2010; Martín-Baró, 1989; 2016).

La dignificación es un proceso que busca sanar los daños ocasionados en un contexto determinado (Zalaquett, 1995, p. 6). Por tanto, se encamina al establecimiento de un proceso psicosocial y jurídico que persigue la dignificación de las víctimas a través de medidas que alivien su sufrimiento: se comprenden sus pérdidas sociales, morales y materiales, y se restituyen sus derechos ciudadanos, enmarcados en la verdad, la justicia y la no repetición (Universidad Nacional de Colombia, 2014). En cierta medida, en contextos donde se han violentado los derechos humanos, las expresiones simbólicas suscitan demandas de reparación y dignificación de las personas asesinadas o desaparecidas. Se exige que se clarifique el porqué de lo acontecido y se concrete en la búsqueda de los restos de los seres queridos a través de ritos públicos y familiares de carácter cultural y religioso (Arzobispado de Guatemala, 1998). Es decir, las víctimas han encontrado en las expresiones simbólicas un posicionamiento político que, según Villa, moviliza la participación de la víctima y la lleva a convertirse en actor social que demanda el cumplimiento de sus derechos, lo que contribuye a rehabilitar el tejido social fracturado por la violencia, que logra posicionarse con dignidad (Villa, 2016). Es por ello por lo que esta investigación posiciona la resistencia social-comunitaria como un elemento que permite a las víctimas de las repoblaciones de Chalatenango transformar su 
dolor, exigir reparación y dignificarse mutuamente a través de la "herramienta política". Esta reparación es comprendida como un entramado de pensamientos, emociones $y$ relaciones sociales que permiten la participación colectiva y el posicionamiento público para la búsqueda de la verdad, el respeto de los derechos humanos y la no repetición de actos violentos (Lira, 1989; Cortina, 2015; Villa, 2016).

Para las repoblaciones de Chalatenango, nunca quedan en el olvido los hechos de barbarie vividos. Desde una mirada crítica de lo que implica dignificarse posterior a un acto deshumanizante, Walter Benjamin (1964) expone que toda movilización colectiva proviene del reconocimiento de la barbarie. Esto implica volver el rostro al pasado y contemplar la acumulación de la ruina, el empobrecimiento y la estupidez. Y ante esta realidad, hay que detenerse para despertar a los muertos y recomponer lo destruido. Vivir en entornos de posconflictos implica escudrinar las esperanzas de las poblaciones, los sueños y los deseos robados. Por ello, el arte se presenta como una herramienta con la que se puede "re-admirar" el quehacer de las personas, un quehacer que ocurre en el dominio de la cultura y de la historia. Como consecuencia, todo acto "re-ad-mirativo" implica la percepción de la percepción anterior de un mismo acto (Freire, 2015).

La educación popular reconoce el protagonismo y el potencial transformador, considerando a las personas como sujetas de su propia liberación (Freire, 2007b). Freire sostiene que la liberación auténtica es la humanización en proceso. No es una cosa que se deposita en las personas. No es una palabra más, hueca, mitificante; es praxis, que implica la acción y la reflexión de los hombres sobre el mundo para transformarlo. En este sentido, la liberación comunitaria supone que no hay humanización sin liberación, así como no hay liberación sin una transformación revolucionaria. Esto implica ser "consciente" para establecer nuevas relaciones humanas en el entendimiento del dolor. Es decir, "ser-exis- tiendo", lo cual significa "ser-siendo-libre". En el entendido de que "el hombre, para ser, ha de hacerse continuamente" (Martín-Baró, 2016, p. 126).

La idea de autonomía para Freire se vincula con la naturaleza humana de "ser más", una eterna búsqueda de consciencia del ser y estar en el mundo, conquistando una libertad que no aprisione al individualismo, sino que le libere para experimentar la vida en comunión, con sus desafíos y conquistas en relación con la humanidad $y$ no en contra de la humanidad (Freire, 2004). La autonomía se va construyendo en la experiencia y en la toma de múltiples decisiones donde se señalan deberes y derechos como personas. "Nadie es sujeto de la autonomía de nadie" (Freire, 2004, p. 49). En la autonomía, los sujetos se convierten en actores sociales involucrados en su realidad a través de un flujo de la conciencia al pensamiento y de este a la práctica. Por lo tanto, en la presente investigación se entenderá la "autonomía" como la capacidad de agencia que los individuos muestran al experimentar su independencia personal y colectiva, a través de la toma de decisiones basadas en criterios propios y de acuerdo a su realidad social, poniendo en práctica una reflexión crítica que implica desafíos y logros que contribuyen al proceso de humanización (Freire, 2004; Martín-Baró, 2006; Boal, 2002).

\section{3. ¿Por qué estudiar la memoria histórica a través de las expresiones de teatro?}

El estudio actual identifica a la posmemoria como un elemento que es parte de la memoria histórica, ya que se incorpora a los estudios desarrollados en eventos postraumáticos como una escena de transmisión entre las generaciones de testigos y herederos de los acontecimientos. Para Hirsch (2012), el concepto de posmemoria ofrece un marco útil para las memorias entrelazadas, actos de transferencia intergeneracional y transgeneracional del trauma, así como sus importantes efectos tardíos (Hirsch, 2012). Además, ella 
nutre esta afirmación con lo que Warburg (1929) denomina un gran "almacén cultural" (tejido social) de formas expresivas prefabricadas (p. 44). Desde estas formas expresivas, las nuevas generaciones se vuelven conectar con el tejido social humano, en el cual reconocen que "su propia existencia es, tal vez, una forma de compensación de una pérdida atroz" (Hirsch, 2012) y que, además, presta un consuelo a través de "tropos paradigmáticos" " de la psicología y la estética. Desde este punto, la transmisión se posiciona como un recorrido afiliativo donde las generaciones se abrazan y hacen la representación de un mundo transformado. Es la conexión con el pasado, por tanto, está mediada no solamente por el recuerdo, sino por una inversión imaginativa, creativa y de proyección (Hirsch, 2012). La "conexión viva" planteada por Hirsch (2012) se manifiesta a través de los rituales cuya relación está mediada por imágenes, relatos, silencios, acciones: síntomas que representan la vivencia experimentada por una persona o por la colectividad (Hirsch, 2012).

Dentro de la posmemoria, la performativa se convierte en un espacio entre la víctima y su ser querido. Un momento lleno de dolor, pero al mismo tiempo de "dignificación a ese dolor” (Melgar, 2019, p. 11). Tanto los testigos de la historia como las nuevas generaciones han experimentado en primera instancia un proceso de duelo. En este proceso, la víctimas comprenden y toman conciencia y señalan los lugares, los nombres, los objetos y las circunstancias en cómo sus familiares fueron asesinados, masacrados, torturados y exiliados durante periodo de guerra. La posmemoria, en este caso, es el performance: la realización de la actividad ritual que incorpora el recuerdo y el reencuentro en el lugar preciso a través de lo simbólico (Hirsch, 2012). Desde este entono, la posmemoria explica la estructura de múlti- ples rupturas y fisuras radicales propias del trauma y modula el legado generacional (Hirsch, 2012). Esta señal podría ser un síntoma de la necesidad de inclusión individual y colectiva dentro de una membrana que incorpora un legado común de múltiples historias traumáticas y que, a la vez, visibiliza el deseo generalizado de reclamar por el pasado como parte indispensable del presente.

El teatro como expresión artística se alimenta de ideas, ademanes, gestos $y$ acciones propias del cuerpo humano. Se acompañan de sonidos y objetos que son distribuidos en un espacio determinado (Fediuk \& Prieto, 2016). A nivel simbólico posibilita la formación de imágenes mentales y ayuda a penetrar en los distintos niveles de la realidad. El teatro es performativo, es cuerpo, es escenario y arma. A través de ello, se hace visible lo que se quiso hacer invisible: los desaparecidos, los crímenes, los culpables.

\section{1. ¿Existe una verdadera reparación social y sentimiento de dignificación?}

"La pregunta ¿Qué hacer con los muertos? reaparece constantemente en gran parte de la narrativa salvadoreña de los últimos años. Esto posee pleno asidero al situar la interrogante en los años que suceden a la firma de los Acuerdos de Paz" (Sarmiento, 2017, p. 395). Es comprensible que esa pregunta surja a raíz del incumplimiento de los Acuerdos, cuando la desilusión se apoderó del ambiente social, de la agenda política, económica y principalmente de la preocupación en la salud: el bienestar social y la calidad de vida de los salvadoreños. Frente a esto, el estudio de la posmemoria muestra que, a pesar de la ausencia de medidas integrales para el presente y el futuro de las generaciones a 41 años de la guerra civil salvadoreña y a 29 años de la firma de los Acuerdos de Paz,

\footnotetext{
6 Transmisión intergeneracional a través de imágenes y códigos histórico-culturales de significación simbólica de fragmentos inmutables de la memoria afiliativa familiar y cultural.
} 
todavía se vive el drama social de muchas familias que perdieron a sus seres queridos por las estructuras paramilitares.

Los jóvenes, al reconocer los hechos violentos que les sucedieron a sus ancestros, se detienen ante esta realidad a través de una mirada compasiva, desde lo testimonial hasta lo estético. Esto posiciona a la posmemoria como "el paisaje que está poblado de rostros del pasado" (Hirsch, 2012, p. 44). Una memoria histórica que se cubre de afecto y efectos psíquicos que pueden ser reelaborados en la comunidad. Para Visitine (2015), reparar significa estar obligado a resarcir el daño; es buscar justicia, comprender el significado de los hechos y asumir constructivamente el dolor y las responsabilidades. Una reparación adecuada y efectiva ha de ser proporcional a la gravedad de las violaciones y al daño sufrido tanto en el plano material como en el inmaterial (Díaz, 2009). Para Gaborit (2006), la reparación social es fundamental a la verdad y busca reconstruir las relaciones interpersonales dañadas, lo cual coadyuva a la reconstrucción del tejido social. Sin embargo, en El Salvador, el fin de la guerra no marcó ningún avance significativo en la reparación social, ni mucho menos en la superación de la impunidad como se planteó desde los Acuerdos de Paz. Ninguna acción legal ha logrado alcanzar la verdad, la justicia y la reparación sobre las graves violaciones de derechos humanos cometidas contra la población civil (IDHUCA, s/f).

En 1992, la firma de los Acuerdos de Paz daba la promesa a las comunidades de encargarse de sus historias a través de la Comisión de la Verdad para El Salvador. Jon Cortina testificó que la institución llegó a las comunidades en octubre de 1992. Además, reconoció la importancia de esta para brindar la oportunidad de hablar a las personas de aquello que les atormentaba. No obstante, esto era "como quitar una tapadera a una olla de presión" (Sprenkels, 2009, p. 36). A pesar de esto, para el sacerdote era importante porque permitía a las personas calmar sus angustias y sus miedos, pues antes tuvieron miedo incluso de llorar a sus muertos. Sprenkels (2012) recalca que la importancia de la Comisión de la Verdad fue la repercusión de la pugna nacional $e$ internacional entre las fuerzas de derecha y de izquierda. Además, permitía "esclarecer con prontitud aquellos hechos de violencia de singular trascendencia, cuyas características y repercusión originaron el reclamo de la verdad" (p. 70). Sin embargo, el mismo Sprenkels (2012-2009) documenta que, aunque el informe de la Comisión de la Verdad fue una prueba valiente e importante, a la vez fue incompleta y carente de profundidad. Pues, con la puesta en vigencia de la Ley de Amnistía, la promesa de justicia quedaba relegada y con ella la esperanza de las comunidades de reencontrarse con sus seres queridos. "Fue como una gran losa que volvió a caer sobre la gente" (Sprenkels, 2009, p. 41).

La negación ante el informe de la Comisión de la Verdad se deriva por el cobijo del "discurso oficial", el cual pide pasar la página. Se trata de instalar el olvido forzado, mediante el cual los responsables plantean su propia versión de los hechos y construyen un sinfín de estrategias que buscan la evitación del recuerdo, la omisión selectiva de acontecimientos importantes, la culpabilización de las víctimas, y responsabilizar a las circunstancias y no a políticas adoptadas por las cúpulas del poder (Baumeister \& Hastings, 1997).

Las comunidades repobladas de Chalatenango, al no tener un reconocimiento sincero de su dolor, ni una búsqueda de preparación integral, han optado por establecer medidas de reparación en el acompanamiento intercomunitario y son ellas quienes siguen exigiendo el reconocimiento y la reparación ante las historias que tuvieron que enfrentar. En este acompañamiento solidario, perciben que "lo primordial en los procesos de reparación es sanar el alma" (Blanco y Gaborit 2007, en Arango et al., 2016, p. 444). Una acción de autocreación en cuanto compasiva ante el dolor y el sufrimiento de un pueblo que ha padecido atropellos, pues en esta realidad que no reconoce los hechos 
de barbarie, "el dolor sigue sintiéndose como sacarnos de la existencia" (Martín-Baró, 2016, p. 106). Así, pues, juntos se encaminan en un proceso de toma de consciencia, donde se reconoce la condición de ser humano en la vivencia de ser y estar en el mundo, confirmando la humanidad, mirándose como sujetos de acción donde se resiste contra la exclusión, la invisibilización, el silenciamiento, y se da lugar a la resignificación de su realidad (Martín-Baró,1964; Freire, 2007; Güendel, 2014).

Ante la ausencia de medidas integrales de reparación que debieran ser ofrecidas por el Estado salvadoreño, ante los hechos ocurridos durante el conflicto armado, esta investigación propone cuestionar lo siguiente: ¿han existido procesos de reparación social para las personas víctimas del conflicto armado? ¿Qué mecanismos o estrategias han utilizado las comunidades repobladas de Chalatenango para acceder a la reparación social? ¿Ha sido la perfomativa teatral un elemento que active la reparación social y la dignificación? ¿Cómo se articula la performativa teatral y la acción política en las comunidades repobladas de Chalatenango? ¿Cómo las expresiones artísticas, específicamente la teatral, han posibilitado procesos psicosociales que contribuyen al resarcimiento del dolor? ¿Cómo estas expresiones de arte abonan a la transmisión de la memoria histórica? Con base en lo anterior, surge la siguiente pregunta de investigación: ¿Ha logrado la performativa teatral activar procesos psicosociales que posibiliten la reparación social y la dignificación en las comunidades repobladas del nororiente de Chalatenango? En caso de activarlos, ¿cómo se han manifestado estos procesos psicosociales? Esta se perfiló en el objetivo general de estudio, el cual buscaba identificar si la performativa teatral ha logrado activar procesos psicosociales que posibiliten la reparación social y la dignificación en las comunidades del nororiente de Chalatenango. Esto se concretó en los siguientes objetivos específicos: primero, indagar si la performativa teatral ha activado un puente intergeneracional de transmisión, reelabora- ción y trascendencia entre los testigos y los herederos de las experiencias traumáticas. Segundo, conocer si la performativa teatral ha estimulado la reelaboración de la identidad comunitaria en las repoblaciones del nororiente de Chalatenango. Tercero, identificar si la performativa teatral ha sido aplicada como herramienta política en la exigencia del respeto de los derechos humanos desde la verdad, la justicia y el compromiso de no repetición. Y, finalmente, cuarto, reconocer si la performativa teatral ha contribuido al desarrollo de autonomía personal y colectiva en las comunidades repobladas del nororiente de Chalatenango.

\section{Aspectos metodológicos}

La presente investigación se desarrolló con un corte cualitativo y se ciñó por un enfoque de tipo hermenéutico. Abordó la realidad social desde una perspectiva subjetiva que comprendió e interpretó los múltiples sentidos de las acciones humanas (Gadamer, 1999). Retomó el enfoque histórico y crítico de las dimensiones: histórica, cultural, sociopolítica, y contextual que englobaron el planteamiento de investigación, de tal manera que permitió explorar y comprender los procesos psicosociales que han propiciado la reparación social y la dignificación en las comunidades repobladas de Chalatenango. Esto se exploró a partir de una entrevista semiestructurada, accediendo a los discursos y al simbolismo que las generaciones dan a las expresiones de teatro referidas a las masacres y guindas que experimentaron durante el conflicto armado (Taylor \& Bogdan, 1992).

Para recoger los discursos se entrevistó a 12 habitantes de las comunidades repobladas de Chalatenango incluidas: Guarjila, San Antonio Los Ranchos, Nueva Trinidad, Las Minas, San José Las Flores y Arcatao. Las y los participantes son ex miembros/as y miembros/as activos/as del teatro comunitario impulsado por dos organizaciones referentes en la zona: Asociación Tiempo Nuevos Teatro (TNT) y las Misioneras y Misioneras de la Memoria Histórica y Ancestral que cumplían 
los perfiles de ser formadoras/es, actrices/ actores y espectadoras/es dentro de cada organización.

La entrevista se realizó con un cuestionario que priorizó el logro de los objetivos, categorías y unidades de análisis de la investigación (Hernández-Sampieri et al., 2014). Las preguntas fueron validadas por tres expertos de acuerdo a tres requisitos esenciales (Hernández-Sampieri et al., 2014): claridad, coherencia y relevancia.

Las y los participantes se seleccionaron de acuerdo al lugar preciso de la realidad en estudio. Su perfil se construyó teniendo en cuenta los casos sensibles para ilustrar de manera idónea los hallazgos del estudio (Flick, 2004). Después de un análisis situacional y experiencial se decidió entrevistar a 2 formadores/as, 2 actores/actrices y 2 espectadores/ as de la Asociación Tiempos Nuevos Teatro, TNT. También se entrevistó a 2 formadores/ as, 2 actores/actrices y 2 espectadores/as de los performances integrados por el Comité de Memoria Histórica Sobreviviente de Arctao y de las Misioneras y Misioneras de la Memoria Histórica y Ancestral, teniendo en cuenta sus experiencias y conocimientos en la disciplina de encuadres teatrales (Flick, 2004).

En consonancia con los cuatro principios generales de la Asociación Americana de Psicología (APA, por sus siglas en inglés), se aseguró el cumplimiento de normas éticas que se contemplan en todo proceso de investigación (APA, 2003). En consecuencia, se elaboró un consentimiento informado que resaltó la estricta confidencialidad de la información. Se plasmaron los derechos que tenían como participantes y se adquirieron compromisos académicos para devolver los resultados de la investigación a través de dos formas: mediante un taller o la entrega de una copia física y/o digital de la investigación.

El proceso de análisis implicó el ordenamiento de tres documentos divididos por roles de las y los participantes (actores/ actrices, formadores/as y espectadores/ as). Seguidamente se inició el análisis en el programa Atlas-ti, a partir de lo que Hernández-Sampieri y otros (2014) llaman: (a) codificación abierta o de primer nivel (comparar unidades). Esto implicó crear categorías y códigos; (b) codificación axial o de segundo nivel (comparar categorías). Esto dio lugar a la interpretación de los datos y desarrollar patrones comunes. Y (c) codificación selectiva, la cual generó enunciados, explicaciones, teorías y narrativas, mismo que concretó los resultados del estudio.

\section{La performativa teatral como activadora de procesos psicosociales en la reparación social y dignificación}

La figura 1 plantea los hallazgos generales en cuanto a la activación de los procesos psicosociales, los efectos y beneficios activados por la performativa teatral en la reparación social y dignificación en las comunidades repobladas de Chalatenango.

La investigación identificó que efectivamente la performativa teatral ha activado procesos psicosociales, los cuales han contribuido en el camino a la reparación social y la dignificación desde y hacia las víctimas. Es decir que, durante el posconflicto, esta se ha convertido en una herramienta de resistencia utilizada como reconstructora del tejido dañado. Esto se ha logrado a través del rescate de las memorias de barbarie y la presentación de las mismas mediante los performances. En ellos, las generaciones buscan abrazar su salud mental mediante un "puente intergeneracional" y su "identidad comunitaria", procesos que vienen desde la activación cognitiva y afectiva. La performativa han seguido un patrón artístico inherente en la historicidad de las comunidades, lo que permite habilitar espacios donde se conmemora, convive, exige, se poner la verdad y libera emociones.

El abrazo intergeneracional ha decidido develar la verdad de lo ocurrido. Estos advierten el efecto de la violencia y posibilita encontrar un sentido al dolor y resignificar el sufrimiento. Entonces, la "autonomía" de 
estas comunidades surge desde las emociones y el reconocimiento de las relaciones humanas de poder. Por esta razón, el teatro se ha convertido en una "herramienta política" que permite denunciar los hechos de barbarie y, a su vez, deviene en una denuncia pública de la no responsabilización del Estado en la búsqueda de la verdad y en no generar procesos de reparación y dignificación.

\subsection{Presentación gráfica de los resultados}

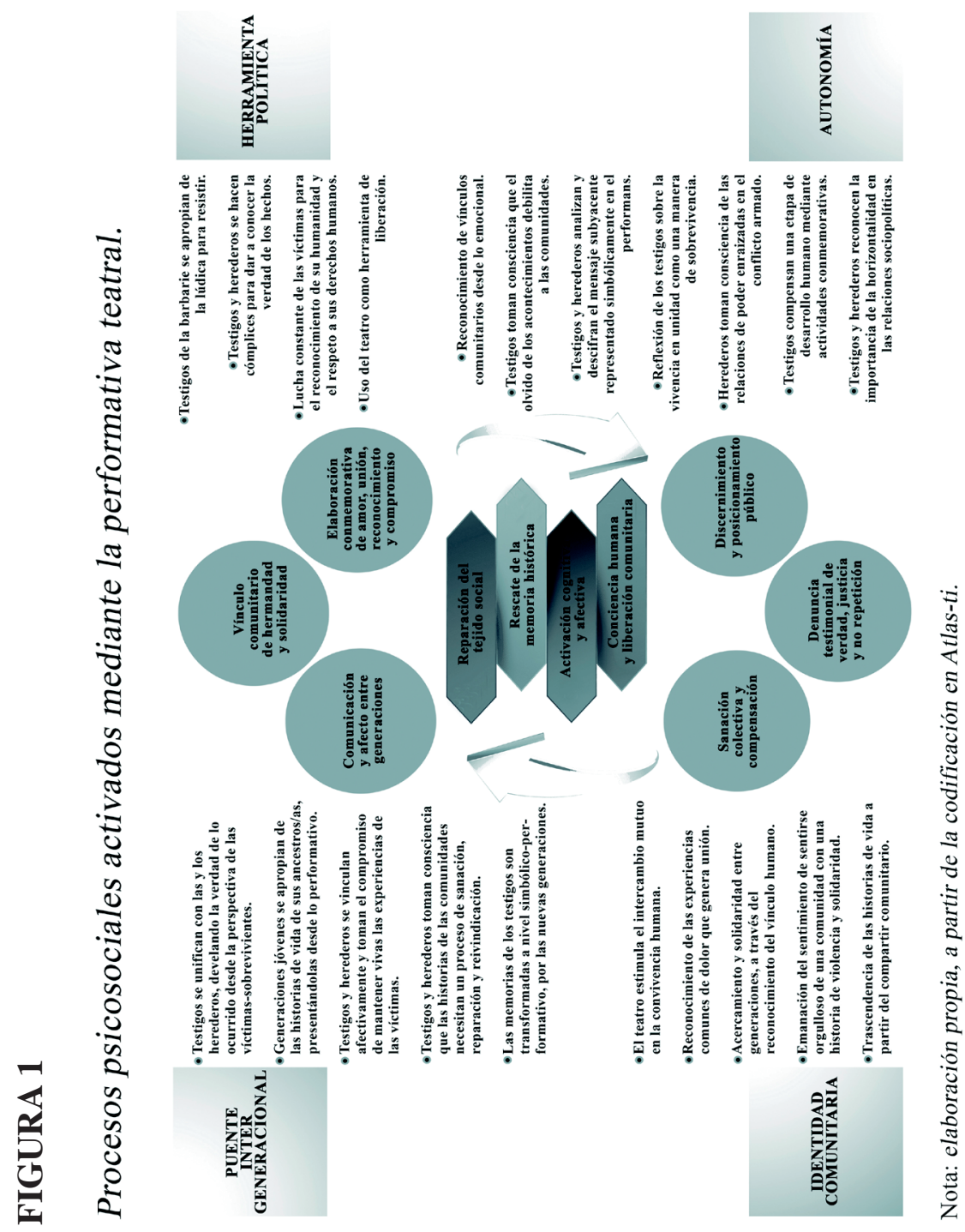




\subsection{Procesos psicosociales activados por categoría de análisis}

En el presente apartado, se recogen los hallazgos que emergieron a partir del análisis discursivo, desde el aporte oral que las personas participantes (formadores/as; actrices/actores; espectadores/as, identificados como testigos-ancestros y herederos-nuevas generaciones) expresaron en sus entrevistas. Estos se desarrollan en dos partes. En la primera, se ilustran los procesos psicosociales activados por categorías de estudio, en consonancia con los objetivos específicos (puente intergeneracional, identidad comunitaria, herramienta política y autonomía) y en consonancia con la presentación gráfica (figura 2), que desarrolla la respuesta a la pregunta de investigación y objetivo general del estudio. La segunda contempla la discusión de resultados, a partir de dos líneas centrales de análisis que se identificaron, las cuales dialogan con los postulados teóricos que sustentan la investigación.

\subsubsection{Puente intergeneracional}

La realidad que se presenta dentro de la performativa teatral de las comunidades repobladas de Chalatenango son los lugares y las historias de catástrofes llevadas a cabo durante el conflicto armado. Es por ello por lo que, en una escena artística simbólica-testimonial, la relación entre el escenario, el actor y la actriz se profundiza cuando los testigos se unifican con los herederos, develando la verdad de lo ocurrido desde la perspectiva de las víctimas-sobrevivientes. Dentro del plano escenográfico, cuando la persona sobreviviente cuenta la verdad de su historia, se convierte en modelo de lucha para sus descendientes. A partir de esto, se activa un vínculo de comunicación intergeneracional, lo que facilita compartir un lugar de la memoria para contarle a los demás todo lo que pasó. La práctica artística aborda claramente la historia de los hechos a través de los testimonios de las personas que los vivieron. En la dramatización realizada en Las Aradas, se realiza el simulacro del río, se representan a parte del pueblo chalateco huyendo de los soldados y cruzándose el río desbordado. La intención de mostrar la verdad de los hechos no es tocar la herida, sino tocar la mente de las nuevas generaciones para que sean conscientes de que sus familiares vivieron toda esta situación y que se provoque, entre las generaciones, un acompañamiento humano. Esto mueve a que las generaciones jóvenes se apropian de las historias de vida de sus ancestros, presentándolas desde lo performativo. En la puesta en escena, los jóvenes validan las vivencias de sus mayores. A través de los afectos, experimentan sentimientos mutuos, provocados por una imagen de lo vivido y sentido, lo que lleva al elenco y al público a entregarse un abrazo simbólico ante la inocencia de las memorias. Esto viene de la atmósfera que generan los espacios artísticos conmemorativos, pues estos propician un cepillar de historias guardadas. En realidad, lo que se está generando es un vínculo con el pasado, es recordar y dignificar esas memorias.

La convergencia artística sirve para activar y unificar la historia. La performativa teatral sirve para ver la forma en la que se vivía en tiempos de guerra. Por eso, el ritual del "Canasunganana" expresa juegos, porque los niños crecieron en medio de asedios y guindas. Con el arrullo de la esta canción de cuna, "se expresa esa forma de cómo jugar en tiempos difíciles".

El performance es útil para experimentar estos sentimientos y emociones en el instante que se "re-actúa" la escena. En ese momento simbólico, los jóvenes manifiestan sentir impotencia, enojo porque en el momento en los que sucedieron los actos violentos no pudieron hacer nada por sus familiares. Sin embargo, a través del teatro es como se puede expresar este "re-encuentro" emocional donde las víctimas, sobrevivientes y las nuevas generaciones se vinculan afectivamente $y$ toman el compromiso de mantener vivas las experiencias. En esta medida, la performativa teatral se vuelve activadora del afecto a través de la "re-contextualización", pues en ella los 
herederos y las herederas experimentan las emociones de sus mayores, empatizan con la historia narrada, puesto que, aunque la repetición escénica es simbólica, concede una mirada no solo mortificante, sino también liberadora. Por ello, durante la escena, tratan de experimentar los sentimientos que las víctimas le trasladan y así transmitirlo al público, teniendo claro que el performace artístico simbólico donde se retratan estos hechos va más allá que el simplemente actuar.

La performativa teatral en las manos de los testigos ayuda a romper los silencios. Es una herramienta que activa la voz de las víctimas, pues si no trasladan sus testimonios se corre el peligro de que las nuevas generaciones repitan la misma historia de sufrimiento. Por lo mismo, los testigos y herederos toman consciencia de que las historias de las comunidades necesitan un proceso de sanación, reparación y reivindicación. Una manera de sanar estas historias es con su participación en el teatro, pues las nuevas generaciones pasan a ser protagonistas en sus procesos de dignificación. En el caso de los testigos, la representación escenográfica les motiva una transición de sentirse víctima a sentirse sobreviviente. Con ello, muestran la solidaridad y la importancia de encontrarse en unidad: "Estamos aquí y nos apoyamos. Somos conscientes de lo que hemos vivido".

En la convergencia artística, tanto los testigos como los herederos convierten una historia de dolor y culpabilidad en un arrullo a la inocencia. Se dignifica su inocencia y paulatinamente se activa un proceso de reconciliación con ella misma, pues los muertos no tuvieron la culpa de lo sucedido. Los que salieron de su casa, las que no salieron, eso era justo lo que tenían que hacer. Dentro de este ambiente cargado de simbolismo, los descendientes arrullan a las víctimas en su proceso de sanación. Así pues, las generaciones adultas encuentran un alivio emocional y se despierta en ellas la confianza que sus memorias se mantendrán vivas de generación en generación.
Cuando las memorias de los testigos son transformadas a nivel simbólico-performativo por las nuevas generaciones, lo que se permite es no negar las cicatrices de una historia traumática, ya que la narrativa oral les ha contado a las nuevas generaciones que sus padres y abuelos fueron asesinados a sangre fría o exiliados de sus hogares. Ante esta realidad, las nuevas generaciones activan procesos psicosociales que problematizan la naturalización social de la violencia y, a través del teatro, se interesan para que estas historias se instalen como una herencia histórico-cultural de trascendencia.

Cuando se realiza una acción performativa que retoma la memoria histórica y que encima de eso se realiza una especie de reparación simbólica para las personas que están contando sus testimonios, lo que se tiene que profundizar es la sensibilidad donde lo oral pasa a lo simbólico desde el texto escrito. Se crea la historia desde el cuento testimonial después escribirlo y luego se representa escenográficamente.

\subsubsection{Identidad comunitaria}

El teatro estimula el intercambio mutuo en la convivencia humana. Durante las conmemoraciones, las comunidades se ven fortalecidas porque la concurrencia artística y simbólica propicia el encuentro intergeneracional e intercomunitario. En ese momento, se conectan y recuerdan su historia $y$, en esa comunicación sin palabras, validan los hechos. Entonces, el espacio físico deja de ser mundano y se convierte en un espacio conmemorativo donde predomina el amor, el compartir y el reconocimiento de la historia común de dolor y solidaridad.

El apoyo mutuo entre comunidades dentro de los performances artísticos recrea un ambiente donde la gente se siente parte. Es un trabajo de memoria con ese sentido de sanación, porque me veo, me identifico, me representa, habla por mí, habla de mí y pertenece a mi comunidad. Desde el arte, lo importante es que se diga lo que se quiere 
comunicar y que se cumpla el objetivo de por qué se hace a través de un proceso creativo. Un objetivo clave es establecer un reconocimiento de las experiencias comunes de dolor que genera unión. Desde ello, tanto el testigo, como el descendiente se ha dado cuenta de que no solo él o ella ha vivido momentos difíciles. Esto genera, en la comunidad, el sentimiento de unión. Conocer estas memorias compartidas permite a los herederos no olvidar esa historia porque es parte de sus familiares y de su comunidad. Además, es una historia que les pertenece y les interpela. En el caso de los testigos, la identificación la sienten, porque dentro de las comunidades conviven con personas que han vivido y viven la misma realidad.

Evidentemente, desde que las generaciones reconocen que viven en comunidades con una historia común, se dan cuenta de que tanto su comunidad como sus familias no son las únicas que han vivido experiencias tan amargas, sino que también las vivió Arcatao, San José Las Flores, San Antonio Los Ranchos, Las Minas y las demás comunidades. La relación intercomunitaria común perfila una lucha por mantener vivos los lugares de la memoria, pues son espacios simbólicos que integran una sanación mediante la evocación de recuerdos y la solidaridad. Este acercamiento y solidaridad entre generaciones, a través del reconocimiento del vínculo humano, activa un carácter transformador del ser, pues, en sí, la plena humanización no tiene otra entrada que a través del afecto con los otros, en su comunidad.

Los jóvenes, como espectadores posmemoriales, sitúan su identificación en la empatía. Dentro de una escena teatral, se colocan en el mismo lugar de las víctimas. Desde ahí perfilan su mirada como descendientes de esa historia y se incentivan por mantenerla viva y conocerla a profundidad. Los testigos, por su parte, se vinculan a las nuevas generaciones realizando un abrazo simbólico, pues dentro del teatro se sienten identificados con lo que se está transmitiendo. Esto aporta a la emanación del sentimiento de sentirse orgullosos de una comunidad con una historia de violencia y solidaridad.

Tanto los testigos como los herederos identifican que sus comunidades, sus montañas y ríos son una tierra sagrada. Reconocen que han sido reconstruidas con sudor, dolor y sangre. Ahí hay dolores y alegrías, alegrías porque se conmemora. Se celebran los dolores como una forma de sobrellevarlos.

Cuando el testigo comunica su vivencia de dolor al descendiente, se valida el sentimiento de pertenencia a una "tierra sagrada", porque se acepta la verdad de los hechos. Por lo tanto, se busca, a través del arte y del simbolismo, la dignificación de esa memoria y son los jóvenes los que se encargan de mantener vivo el legado histórico. Así, se estimula la trascendencia de las historias de vida a partir del compartir comunitario. En ese abrazo simbólico intergeneracional, se trasmite energía y ánimo de lo que se vivió y se sigue viviendo. En esta comunicación intergeneracional, se lleva desde la construcción artística; la juventud entrevista a sus ancestros, quienes vivieron los acontecimientos de barbarie y solidaridad. Este acercamiento aporta información que ha estado por años en lo privado y ayuda a que los jóvenes se vuelvan conscientes de lo que pasó y, en esa medida, serán ellos los que continúen la lucha y sepan que el país merece continuar con procesos de justicia. Es una tarea para transformar.

El anhelo de los testigos, al establecer este vínculo, es para que se conozcan las raíces, para que los hechos no vuelvan a ocurrir, a la vez que se enorgullecen al heredar sus memorias a las nuevas generaciones, pues en ellas no solo transmiten sufrimiento y dolor, sino también heredan una historia de unidad y solidaridad.

\subsubsection{Herramienta política}

Los testigos de la barbarie se apropian de la lúdica para resistir. Durante el conflicto armado, las comunidades fusionaron el teatro con la música, la poesía y la creatividad para tener un momento de distracción dentro del 
ambiente hostil. Los "teatrillos" eran una forma de resistir a las condiciones atroces que habían irrumpido su cotidianidad y transgredido sus derechos humanos. Una testigo de la brutalidad comenta: "Si venían las 'masas' del lado de Guazapa, huyendo de los operativos militares, nosotros nos movíamos con todo el 'jelengue' y decíamos: 'hay que irles a cantar, a hacer bailes, a presentar un teatrillo o lo que fuera'. Lo importante era levantarles el ánimo y decirles: 'miren, señores, han llegado a este frente y vamos a estar juntos'. Hacer expresiones de arte era como decir: "no nos hemos muerto, así que vivamos el momento'”.

Actualmente, el testimonio es, en sí mismo, una denuncia simbólica que ayuda a mantener viva la memoria histórica y motiva a las nuevas generaciones para acercarse a sus ancestros y exponer sus memorias mediante el performance. Por consiguiente, se activa un posicionamiento público que permite al testigo $y$ al heredero resistir, en unidad, ante la falta de reconocimiento de los actos de barbarie vividos y la ausencia de reparación por parte del Estado salvadoreño. Por lo mismo, través del teatro, los testigos y herederos se hacen cómplices para dar a conocer la verdad de los hechos. Dejan ver los testimonios de las personas que estuvieron presentes y sufrieron cierta masacre. Por lo mismo, posterior a la escena emerge el diálogo intergeneracional y surgen opiniones sobre el montaje de lo observado. Durante el intercambio verbal producto de las impresiones del performance, se abona a la reconstrucción de la escena y, a partir de la remembranza, surgen nuevos elementos para ser incorporados en posteriores presentaciones. Es así como emerge la reconstrucción colectiva de la memoria, la cual cobra especial énfasis en la exigencia de no repetición. Es decir que, para ellos, transmitir memorias a las nuevas generaciones significa conocer las causas de la barbarie para intentar transformarlas. Es estar consciente de que, mientras perduren estas causas, existe la posibilidad de que la barbarie vuelva a ocurrir.
En la actualidad, los performances elaborados por los testigos y herederos se cargan de consignas, artes gráficas (mantas, carteles $\mathrm{u}$ otros) exigiendo justicia $e$ invitando al espectador a situarse en el pasado. Pero igualmente los invita a ubicarse en el presente $\mathrm{y}$, de manera colectiva, provocar una sensación de alivio que se deriva del acompañamiento intercomunitario. El teatro ayuda a soltar ese sentimiento de dolor retenido, mismo que motiva una lucha constante de las víctimas para el reconocimiento de su humanidad y el respeto a sus derechos humanos. Durante los encuentros comunitarios, se desata un clima de acompañamiento psicoafectivo que permite a los testigos sentirse acogidos en su dolor. En consecuencia, se genera un dolor compartido y asumido por los herederos. El teatro armoniza el posicionamiento público de los sobrevivientes, quienes mantienen claridad de que el respeto a los derechos humanos, y el resarcimiento de los vulnerados es fundamental para provocar la sanación colectiva. Con este reconocimiento de su historicidad de dolor, sufrimiento y transformación de la vivencia en acciones propositivas, se enfatiza el uso del teatro como herramienta de liberación, pues este desde sus inicios se concibió como estrategia de reflexión. Luego se migró a un enfoque informativo, reivindicativo y de exigencia al Estado y, finalmente, se mantiene como un mecanismo de reparación, sanación simbólica y liberación, que se fusiona con el vínculo afectivo intergeneracional.

Justo en este punto, donde se instala una conexión psicoafectiva y reivindicativa entre las generaciones posconflicto, las comunidades simbolizan el dolor, pero no desde el dolor mismo, sino desde la transformación de ese sentimiento. Una acción social que convierte la historia en una escena dignificante y sanadora. Ante ello las generaciones, reflexionan que cuando cantan el "Canasunganana", en la escena, se arrulla el pasado que duele, pero que se necesita contar para sanar. Entonces, la canción de cuna se convierte en un activador de un proceso de amor y sanación. Es una manera de arrullar el dolor. 


\subsubsection{Autonomía}

El reconocimiento de vínculos comunitarios desde lo emocional activa una conexión humana, la cual trasciende y queda instalada en el tejido comunitario. Al abrirse e instalarse esta conexión, el testigo y el heredero encuentra un ambiente de armonía, confianza y amor, lo cual hace que los confíen sus testimonios y vivencias hasta que emana una sensación de liberación. De esta manera, surge un lazo de confianza y afecto entre las dos generaciones que permite entretejer una conexión consanguínea, de historia, de recuerdo, de memoria y de pertenencia comunitaria. Desde este escenario social, los testigos y herederos toman consciencia de que el olvido de los acontecimientos debilita a las comunidades. Sin embargo, también reflexionan que el aporte que presta la dinámica performativa activa el recuerdo. Para ellos, olvidar es imposible, porque atenta en el debilitamiento comunitario y el nivel de organización. Por esta razón, expresan que el teatro sirve para no perder la brújula de donde se viene. Ante este panorama, los testigos y herederos asumen un compromiso y la responsabilidad por buscar el reconocimiento de su huella histórica, donde analizan $y$ descifran el mensaje subyacente representado simbólicamente en el performance.

La escena provoca en el heredero el interés por la recuperación de la memoria historia y sobre todo se motiva a reflexionar críticamente sobre lo que observa. El testimonio verbal para transformarse en performance requiere de una activación cognitiva y afectiva para llegar a ser arte gráfico. Por ello, los testigos y herederos entran en una dinámica de "co-construcción" que permite mostrar una escena cargada de memorias. Por lo mismo, se tiene claro que en el teatro las imágenes dicen más que las palabras. Así, las expresiones físicas provocan emoción. En ese momento, los simbolismos, como una muñeca, un vestido, una luz, un candil, una vela, un abrazo perdura más en la mente de la persona espectadora y permite una reflexión de los testigos sobre la vivencia en unidad como una manera de sobrevivencia.

Durante el conflicto, la amenaza de operativos militares obligó a los testigos a mantenerse unidos, cuidándose unos a otros. Las personas se cuidaban mutuamente y realizaban en conjunto los tatús, lugares donde se refugiaban cuando había amenazas. Lo hacían pensando en el bienestar de la mayoría. Esta fue una dinámica social que perduró después del conflicto armado, pues en Mesa Grande establecieron su organización $y$ ese mismo colectivismo lo implementaron en las comunidades cuando se repobló. Los comités que habían establecido en los campamentos también los elaboraron durante la reconstrucción comunitaria.

Pese a que la modernidad atenta fuertemente con la irrupción del sentir y el ser colectivo, los testigos, que participan en actos conmemorativos y escenas de teatro, se esfuerzan por no abandonar el estilo de vida solidario y de organización comunitaria que adoptaron en la lucha revolucionaria. Por ende, lideran un esfuerzo permanente por remembrar y fortalecer vínculos de unión para enfrentar los desafíos actuales; pues, desde la experiencia vivida, saben que esta es una manera de salir adelante y reparar desde dentro lo dañado por las circunstancias sociopolíticas del momento histórico vivenciado. Del mismo modo, los herederos toman consciencia de las relaciones de poder enraizadas en el conflicto armado. Por ende, en los procesos de formación artística, el teatro propone una acción de consciencia política y social que evidencia las condiciones que afrontaron los testigos, previas al conflicto armado. Esto permite que los herederos realicen un discernimiento sobre la realidad de la época e interpreten la razón de la toma de decisión político-revolucionaria que emergió. Ante el reconocimiento de la historia, los herederos junto a los testigos toman un posicionamiento público que les permite opinar sobre su historia personal y comunitaria con propiedad. Se apropian de las causales del conflicto y van volviéndose conscientes de 
que únicamente desde el contexto microsocial, con participación activa, reflexión crítica y organización comunitaria, se puede provocar el bienestar socioeconómico anhelado durante décadas.

\section{Conflicto armado y teatro: desconexión y reconexión con el vínculo humano}

\subsection{Ruptura del tejido social}

La violencia sociopolítica que desencadenó el conflicto armado salvadoreño propició una ruptura del tejido social en las comunidades repobladas de Chalatenango. Esta ruptura evidencia una mirada asesina nacionalista desde la institucionalización de la violencia, acción que se concreta en lo que Martín-Baró (1990), Samayoa (1987-1990) y Oropeza (1990) llaman "deshumanización", pues son un cúmulo de acciones enajenantes donde se concibe a las demás personas como desiguales. Son acciones sociales que se legitiman desde un orden social que parece despreciar la vida humana. Desde la visión del uso instrumental de la razón, Adorno (1998) percibe los contextos de barbarie como un esquema donde perduran las condiciones que la hicieron posible" (p. 80). La ruptura del tejido social, durante el conflicto, retrata a una parte de la población incorporada a la Fuerza Armada, otra a la guerrilla y una tercera en los hermanos que se quedaron en el fuego cruzado de los dos bandos: la población civil. El caos social de esta experiencia se concretizó en la crueldad de decisiones políticas de alto nivel, donde quien muere y quien mata es la misma población: "pobres matando pobres, dirigidos por gente millonaria".

La barbarie vivida en los años del conflicto armado no se quedó en estas épocas. Las narrativas han florecido del pasado tornando su corola en virtud de un secreto heliotrospismo (Benjamin, 1940). Describir las condiciones en las que vivían las comunidades durante el conflicto armado permite descubrir historias genocidas, las cuales fueron silen- ciadas en largo tiempo, aun en los senos familiares. Según señala Hirsch (2012), estas historias que no han sido contadas, sino sintomáticamente "re-actuadas" entre las generaciones, se han convertido en la memoria prohibida de la muerte que se manifiesta en incomprensibles ataques de pena (Hirsch, 2012, p. 167). Por ello, desde las suposiciones del discurso oficial, se rechaza el miedo de afrontar el trauma del pasado. En sí, el discurso oficial funciona como "escudo protector o piel psíquica que regula el tránsito de estímulos y de información en la frontera con el yo" (Santner 1992, en Hirsch, 2012); pone al olvido $y$ al silencio como escudos protectores desde el "escapismo palpario".

El olvido lleva a la distorsión de la memoria, un silencio impuesto por las circunstancias, mismo que se escabulle en historicidad de las comunidades repobladas prestando poca importancia a la salud mental de las víctimas. También olvida el reconocimiento moral-social de los hechos y la responsabilidad del Estado frente ellos. Una imposición al recuerdo lo vieron las comunidades, posteriormente a la firma de los Acuerdos de Paz, ya que muchas memorias fueron silenciadas. Estas apenas se asomaban en conversaciones esporádicas entre testigos en su vida cotidiana. El posconflicto carga un olvido impuesto desde los silencios, pues en muchas familias el silencio se queda en la "re-actuación" de fases que no quieren contar porque hay mucho dolor en ellas. La posmemoria pone en perspectiva que las nuevas generaciones han tenido que vivir con estas rotas y fallidas relaciones humanas. Ante esto, se toma en cuenta que, cuando los testigos no trasladan los testimonios de una manera saludable, las nuevas generaciones viven con el riesgo de repetir la misma historia de sufrimiento. Entonces, el olvido y el silencio escapistas se convierten en la nueva ruptura del tejido social que no deja caminar al heredero hacia su propia libertad.

En sí, un conflicto armado se convierte en un lugar de dolor, de tristezas, de muerte, de secuelas, de abandono, de exilio, de pérdida 
de ombligo y de resistencia. Es una ruptura tal del tejido social que las comunidades quedan con el sentimiento de no querer vivir algo semejante, ni que sus descendientes lo vivan en tiempos posteriores. Quedan las secuelas de esos dolores, principalmente porque ante los intereses dominantes el tema de justicia es irrelevante.

\subsection{Reconstrucción del tejido social}

Es evidente que las repoblaciones en su devenir histórico-político han procesado su vivencia traumática desde lo que Martín Baró (1964) llamo "sufrir con sentido". Ello se ha manifestado mediante el acompañamiento intercomunitario, en donde se confortan mutuamente y enfrentan los efectos de la impunidad. Aún llevan consigo el dolor de las múltiples pérdidas, pero transformadas en solidaridad y empatía para con los otros. El reconocimiento colectivo de sus historias deriva de la conexión emocional que surge entre el testigo y el heredero durante la dinámica sociocultural. Con ello, fortalecen el vínculo social y humano (Warbury, 1929, en Hirsch, 2012) que la guerra les arrebató (Hirsch, 2012).

Ante una realidad testimonial que conmociona, los herederos enfrentan emociones de ira e impotencia, pues reconocen que en la época del conflicto armado no pudieron hacer nada, pero el teatro les ofrece la oportunidad de representar $y$, a la vez, reivindicar la historia. A través del teatro, se permiten develar y señalar responsabilidades; despertar las emociones y acogerlas mediante un arrullo simbólico de amor y compromiso, pues son conscientes de que las secuelas emocionales marcan la vida individual, como también la colectiva. Tanto el testigo como el heredero enfatizan que lo que se opacó con los silencios hoy surge como potenciales vínculos de unificación. Esto lleva a que se muestren con autonomía (Freire 2015). Por lo mismo, se apropian de un espacio político que da a conocer la verdad de los hechos y, desde ahí, mantienen la conexión viva entre las generaciones pasadas y venideras (Hirsch, 2012).
La participación en las performativa teatral desvanece cualquier forma de fatalismo, puesto que el teatro activa el raciocinio $y$ la emotividad. La escena provoca lágrimas, tristezas, recuerdos traumáticos, anhelos de justicia y reparación. Y, a su vez, la exteriorización de dichas emociones, que son subjetivas en cada persona u colectividad, como si el testimonio hecho palabra fuese desvaneciendo el dolor, pero no la memoria. La concienciación de la experiencia de vida ha tenido una vertiente circular en las personas sobrevivientes, la cual ha sido experimentar la emoción, vivirla, compartirla, reconocerla en otras y otros, y hacerse conscientes de que la violencia recibida no borró lo más importante de su vida, su humanidad. Finalmente, logran que las memorias se queden depositadas en la intersubjetividad colectiva (archivo de la memoria), pues mientras exista el arte teatral, estas no se enfriarán, ni morirán (Adorno, 1998).

Se reconoce que la vivencia es la principal arma de sanación. Contar lo vivido y sentirse acogido en el dolor hace que este sea digerible. El recuerdo, la simbolización de este en el performance es una estrategia fundamental para posicionarse desde la verdad y desde la vinculación afectiva que permite espejearse en el otro (Montero 2010). Reconocerse e identificarse evidencia la reconexión comunitaria que motiva un sanar con amor (Hirsch, 2012). La esencia humana herida en épocas de guerra sana en el intercambio y en el acompañamiento, aspecto fundamental enfatizado por Freire (1975); pues, para él, la liberación auténtica es la humanización en proceso. En definitiva, ha sido la humanización, la unión y el amor lo que ha contribuido firmemente a que estas comunidades se visualicen como un ejemplo de praxis liberadora (Freire, 1975). Han resignificado su vivencia, la han transformado en sanación y han reflexionado el curso de sus vidas. 


\section{Conclusiones}

Al inicio se hizo esta pregunta: cha logrado la performativa teatral activar procesos psicosociales que posibiliten la reparación social y la dignificación en las comunidades repobladas del nororiente de Chalatenango? En caso de activarlos, ¿cómo se han manifestado estos procesos psicosociales? Los datos recabados afirmaron que las expresiones teatrales se han convertido en una de las múltiples estrategias implementadas por las comunidades para emprender una lucha reivindicativa que se contrapone al status quo que se ha encargado de invisibilizar la memoria histórica comunitaria con el devenir de los años. Es decir que el teatro ha fungido como potenciador de nuevas dinámicas relacionales intercomunitarias que se focalizan en acoger el sufrimiento y transformarlo en praxis liberadora.

En relación con los objetivos, se identificó que la performativa teatral ha activado procesos psicosociales que apuestan a la dignificación desde y hacia las víctimas. A partir de las vivencias y la convivencia, ha activado un puente intergeneracional de transmisión, reelaboración y trascendencia de las experiencias traumáticas que se concretiza en una conexión emocional que propone el inicio de procesos de sanación que sirven para recuperar y reivindicar la memoria histórica. El teatro también provoca un arraigo comunitario desde la apropiación del dolor, reivindicación y transformación de este. La reelaboración de la identidad comunitaria se afirmó al identificar el sentido de pertenencia en espacios físicos y simbólicos mediante los performances. Esto permite a las comunidades ir sanando y reconocer que sus comunidades son una tierra sagrada que acoge muchos inocentes en su seno. También, el teatro se ha utilizado como una "herramienta de resistencia" que permite la apertura de espacios idóneos para exteriorizar el dolor, celebrar la vida y denunciar los hechos de barbarie. El teatro, además, señala la no responsabilización del Estado en la búsqueda de la verdad y en generar procesos de reparación y dignifica- ción. El teatro es esa herramienta de denuncia testimonial desde las víctimas, la cual se encamina hacia la verdad, la justicia y la no repetición de hechos atroces ocurridos. Por último, se reconoció que, mediante la performativa teatral, los pobladores de las comunidades se perciben como entes que se posicionan con seguridad ante su propia realidad. Así, estas personas buscan constantemente visibilizar los testimonios personales, familiares y comunitarios con el objetivo de mantener un pensamiento transformador que busca incansablemente el bien intercomunitario desde el fortalecimiento de la convivencia y la resistencia ante la heteronomía impuesta durante el conflicto armado. Por lo mismo, se utilizan los performances como potenciadores de reflexión crítica de la realidad, se fomenta la consciencia social y de sanación colectiva.

\section{Referencias bibliográficas}

Adorno, T. (1998a). Dialéctica de la ilustración. Trotta.

Adorno, T. (1998b). Educación después de Auschwitz. En T. Adorno, Educación para la emancipación. Conferencias y conversaciones con Hellmut Becker (1959-1969) (pp. 79-92). Morata.

Adorno, T. (1970). Teoría estética. Akal.

Aguiluz, R. A. (2014). El problema agrario en El Salvador de la Modernización a la Reforma Agraria, 1948-1979 [Tesis de Licenciatura en Economía]. Universidad de El Salvador.

Arzobispado de Guatemala. (1998). Guatemala: Nunca Más. I. Impactos de la violencia. Oficina de Derechos Humanos del Arzobispado de Guatemala.

Ascoli, J. F. (1994). Tiempo de guerra y tiempo de paz. Organización y lucha de las comunidades del nor-oriente de Chalatenango (1974-1994). Equipo Maíz.

Baumeister, R. F. \& Hastings, S. (1997). Distortions of collective memory. How group flatter and decesive themselves. En J. W. 
Pennebaker, D. R. Páez \& B. Rimé (Eds.)., Collective Memory of Political Events (pp. 277-293). Lawrence Erlbaum Associates.

Boal, A. (2002). Teatro del oprimido: juegos para actores y no actores. Alba Editores.

Cardenal, R. (2008). Historia de una esperanza. Vida de Rutilio Grande. UCA Editores.

Ciancio, B. (2015). ¿Cómo (no) hacer cosas con imágenes? Sobre el concepto de posmemoria. Constelaciones. Revista de Teoría Crítica, 7(7), 503-515. http://constelaciones-rtc.net/article/view/1128

Cuesta, R. (2018). WALTER BENJAMIN: Sobre el concepto de historia (1940). Conversaciones sobre la Historia. https:// conversacionsobrehistoria.info/2018/09/23/ walter-benjamin-sobre-el-concepto-de-historia-1940/?

Díaz, I. (2009). El rostro de los invisibles víctimas y su derecho a la verdad, justicia, reparación y no repetición. Biblioteca Virtual del Centro de Estudios de Justicia de las Américas. 1-24.

ECA. (1997). 1970-1992: Dos décadas de violencia sociopolítica en El Salvador. http:// www.uca.edu.sv/publica/eca/588com1.html

Fediuk, E. y Prieto, A. (2016). Corporalidades escénicas: representaciones del cuerpo en el teatro, en la danza y el performance. Universidad Veracruzana.

Freire, P. (2015). Pedagogía de los sueños posibles. Por qué docentes y alumnos necesitan reinventarse en cada momento de la historia. Siglo XXI Editores.

Freire, P. (2007b). La educación como práctica de libertad. Siglo XXI Editores.

Gadamer, H.-G. (1999). Verdad y método. Sígueme.

Gaborit, M. (2006). Memoria histórica: Relato desde las víctimas. Pensamiento Psicológico, 2(6), 7-20. https://www.redalyc. org/pdf/801/80100602.pdf
Grenni, H. (2010). Monseñor Romero: diálogo y conflicto. Revista de Teoría y Praxis, 18, 25-50. http://rd.udb.edu.sv:8080/jspui/ bitstream/11715/812/1/4.\%20Monsenor\%20 Romero-\%20dialogo\%20y\%20conflicto.pdf

Grenni, H. (2008a). Monseñor Romero y el golpe de Estado del 15 de octubre de 1979. Revista de Teoría y Praxis, 13, 25-52. http://rd.udb.edu.sv:8080/jspui/bitstream/11715/741/1/2.\%20Monsenor\%20 Romero\%20y\%20el\%20golpe\%20de\%20 estado\%20del\%2015\%20de\%20octubre\%20 de\%201979.pdf

Hernández, A. G. (2016). Cartografía de la memoria: actores, lugares, prácticas en $\mathrm{El}$ Salvador de posguerra (1992-2015). [Tesis doctoral]. Universidad Autonóma de Madrid.

Hernández, R., Fernández, C. y Baptista, P. (2006). Metodología de la investigación. McGraw-Hill.

Hernández Rivas, A. G. y Chévez Reynosa, C. I. (2018). Ciudadanía, memoria y cultura de paz en El Salvador. Auschwitz Institute for Peace and Reconciliation $y$ Ministerio de Educación de El Salvador. http://www.auschwitzinstitute.org/wp-content/ uploads/2019/01/AIPR_El-Salvador2_Final.pdf

Hirsch, M. (2012). La generación de la posmemoria: escritura y cultura visual después del Holocausto. Carpe Noctem.

Lara-Martínez, C. B. (2018). Memoria história del movimiento campesino de Chalatenango. UCA Editores.

Lira, E. (1989). Consecuencias psicosociales de la represión política en Chile. En L. de la Corte, A. Blanco y M. Sabucedo (Eds.), Psicología y derechos humanos (pp. 143-152). Icaria Editorial.

Lira, E. (2004). Políticas de Olvido, Resistencias de la Memoria y Ética de los Investigadores. Chile. En V Congreso Chileno de Antropología. Colegio de Antropólogos de Chile A. G., San Felipe. https://www. aacademica.org/v.congreso.chileno.de.antropologia/143.pdf 
Martín-Baró, I. (2006). Hacia una psicología de la liberación. Revista Electrónica de Intervención Psicosocial y Psicología Comunitaria, 1(2), 7-14. https://webcache. googleusercontent.com/search?q=cache: $1 \mathrm{~d}$ 0j9HllOzAJ:https:/dialnet.unirioja.es/servlet/ articulo\%3Fcodigo\%3D2652421+\&c$\mathrm{d}=2 \& \mathrm{hl}=$ es-419\&ct $=\mathrm{clnk} \& \mathrm{gl}=\mathrm{sv}$

Martín-Baró, I. (2016). El realismo crítico. Fundamentos y aplicaciones. UCA Editores.

Martín-Baró, I. (1998). Psicología de la liberación. Trotta.

Martín-Baró, I. (1990). Psicología social de la guerra: trauma y terapia. UCA Editores.

Martín-Baró, I. (1989). Sistema grupo y poder. Psicología desde Centroamérica II. UCA Editores.

Martín-Baró, I. (1988). La violencia política y la guerra como causas del trauma psicosocial en la guerra de El Salvador. Revista de Psicología de El Salvador, 7(28), 123-141. https://www.uca.edu.sv/coleccion-digital-IMB/ wp-content/uploads/2015/11/1988-La-violencia-pol\%C3\%ADtica-y-la-guerra-como-causasdel-trauma-RP1988-7-28-123_141.pdf

Martín-Baró, I. (1983). Acción e ideología. Psicología social desde Centroamérica. UCA Editores.

Martín-Baró, I. (1964). Sufrir y ser. Teoría y Crítica de la Psicología, 6, 372-414. http:// www.teocripsi.com/ojs/

Melgar, N. (2019). iNo borrarán nuestra memoria! Víctimas: memoria y olvido. Cátedra Colectivos en Riesgos. Maestría en Intervención Social. UCA El Salvador.

Melgar, N. (2015). Nací en un país prestado (no publicado).

Merino, S., Pacheco, G., Portillo, S. y Ramírez, F. (2011). Análisis estructural del sector agropecuario en El Salvador: Evolución e implicaciones en la seguridad alimentaria del sector rural. UCA El Salvador.

Molina, M. N. y Kovalskis, M. Y. (2017). El Salvador (1980): diferencias entre los decretos de la primera y la tercera fase de la reforma agraria. Revista Electrónica de Estudios Latinoamericanos, 39-53. https://www.redalyc. org/pdf/4964/496454146003.pdf

Montes, S. (1986a). Levantamientos campesinos en El Salvador. Realidad Económico y Social, 1, 79-100. https:// www.lamjol.info/index.php/REALIDAD/issue/ view/726

Montes, S. (1985b). Desplazados y refugiados salvadoreños. Revista de Relaciones Internacionales, 13, 9-21. http://repositorio. uca.edu.sv/jspui/bitstream/11674/2325/1/ Los\%20desplazados\%20y\%20refugiados $\% 20$ salvadore\%C3\%B1os.pdf

Montero, M. (2004). Introducción a la psicología comunitaria. Desarrollo, conceptos $y$ procesos. Paidós.

Organización de las Naciones Unidas (ONU). (1992-1993). De la locura a la esperanza. La guerra de 12 años en El Salvador. Informe de la Comisión de la Verdad para El Salvador. PNUD.

Radio Farabundo Martí. (2020). 38 años de la masacre de la Guinda de Mayo. Facebook. https://www.facebook.com/Radiofarabundomarti98.1fm/ videos/2412965865662060

Rivera, R. (2003a). De la guerra a la paz. Análisis dialéctico del proceso histórico salvadoreño. Realidad: Revista de Ciencias Sociales y Humanidades, 95, 667-701. https://doi. org/10.5377/realidad.v0i95.4227

Santner, E. (1992) History Beyond the Pleasure Principle: Some Thought on the Representation of Trauma. En Probing the Limits of Representation. Nazism an the Final Solution (pp. 143-154). Harvard University Press.

Sarmiento, I. (2017). ¿Qué hacer con los muertos? Claudia Hernández y el trabajo del duelo en la postguerra salvadoreña. Revista Canadiense de Estudios Hispánicos, 41(2), 395-415. https://www.jstor.org/ stable/26310065 